\title{
Prison and Immigration Industrial Complexes: The Ethnodistillation of People of Color and Immigrants as Economic, Political, and Demographic Threats to US Hegemony
}

\author{
Jesse Díaz Jr.
}

Department of History, Politics and Society, La Sierra University, Parkway Riverside, CA 92515-8247, USA

\begin{abstract}
This paper compares the sociohistorical trends that led to the development of the Prison and Immigration Industrial Complexes by demonstrating their deep roots in American public, racial, political, and penology history, and to show how these industries were used as armaments in the low intensity conflict war to keep blacks "in their place" in the post-Civil Rights Movement era, and now against Latino immigrants in a last ditch effort to preserve a dissipating white hegemonic order as the looming Browning of America unfurls. This study specifically compares the black experience in the Prison Industrial Complex, and how local policies fuel that industry, to the immigrant experience and how the Immigration Industrial Complex lucratively thrives from federal and regional antiimmigrant policies that have fueled its expansion along the border, thereby escalating the "War on Drugs" to the "War on the Border." Scholars have argued that the Prison Industrial Complex ultimately serves to "disappear" people of color from society. I extend that contention to the Immigration Industrial Complex, by arguing that the white ruling class has benefitted the most because countless whites have escaped the wrath of these industries, which is coupled by its motivation to "purify and refine" society, more specifically to "distill" it of the "hypercriminalized" class theoretically composed of people of color in a process previously established as ethnodistillation, which have served to maintain the US' white subjugated social order.
\end{abstract}

Keywords: Immigration, Immigration and Crime, Immigration Industrial Complex, Prison Industrial Complex, Mass Imprisonment, Prisons, Immigration and Customs Enforcement, Detention Centers.

\section{INTRODUCTION}

Rapt in their "get tough on everything" trance, Americans sit idly by as private "prison profiteers" at the helm of a behemoth private prison industry pilfer the "bottomless" congressional coffers lining their pockets with billions of US tax dollars. Political activist, Angela Davis, posited mass imprisonment is now the response of first resort to far too many societal problems that burden people ensconced in poverty, "Prisons do not disappear the problem, they disappear human beings. The practice of disappearing vast numbers of people, of poor immigrants and racially marginalized communities, has literally become big business" (1998: 1). Since the 1980s, the Prison Industrial Complex has entrenched itself into American history. By exploiting millions of inmates, a handful of profiteers have gained fruitfully, to the degree that "The appearance of the prison millionaire [has] marked a turning point in American penology. Never before had it been possible in this country to become rich incarcerating other people. Now it seems commonplace" (Hallinan, 2001: 174).

There is a comparable system disappearing immigrants, not meant for behavioral adjustment but to

*Address corresponding to this author at the Department of History, Politics and Society, La Sierra University, La Sierra Hall, Room 302, 4500 Riverwalk Parkway Riverside, CA 92515-8247, USA; Tel: 951.785.2065;

Fax: 951.785.2442; E-mail: jessediazjr@gmail.com merely warehouse individuals in "limbo" awaiting hearings, deportation, or to be bonded out ${ }^{1}$. According to Fernándes (2007), "The attempts to criminalize immigrants, whether they have entered the United States permissibly or not, and by paralleling them to the terrorists who attacked the US, fuels policy that created a profit-making "Immigration Industrial Complex" centered around detention and deportation." The detention industry research has attempted to explain its role and expansion (Brotherton \& Kretsedemas, 2008; Díaz, 2011; Douglas \& Sáenz, 2009; Golash-Boza, 2009a, 2009b; Fernándes, 2007; Schlosser, 1998).

\section{How Policies Have Shaped Mass Imprisonment in the US and the Road to the New Jim Crow}

This snapshot analysis of the black experience in the Prison Industrial Complex, and Latino immigrants in the expanding Immigration Industrial Complex will discuss how lucrative it has been to mass imprison and detain both groups. To support the general premise of this study, which is that the hegemonic order in the US is protected and maintained by "disappearing" certain populations, I argue also that federal legislative policies

\footnotetext{
'This is firsthand testimony from a former detainee in Raymondville facility in Texas in 2009. She learned that many detainees were able to post bond but were unable to because their families did not know where they were, or they could not raise even minimal amount bonds, and therefore were forced to stay in detention with little to no way out, especially because they did not have family or friend sponsors living in the states.
} 
such as the "War on Drugs," has evolved into a "War on the Border," and will show how these "wars" have been employed to inundate US private prisons with millions of inmates of color that has garnered for private prison profiteers billions of dollars. Furthermore, it can be argued that the escalation of these "wars" has grown to include the expansion of the "drone surveillance program" along the US border and well into its interior, which is inherently linked now to the persistent "War on Terrorism," giving credence to the "low intensity conflict doctrine" discussed below that is now threatening to become a "War on Americans."

This paper also highlights the parallels relative to how damaging these private prison industries have been to blacks by infringing on their constitutional right to privacy while on probation and or parole, stripping away their democratic right to vote, and basic right to equal employment, and to immigrants entering the system which involves stripping away their work, school, and visiting visas, driver's licenses, passports, and basic right to work-and has separated detained parents from their children forcing thousands of their sons and daughters into fostercare.

Despite the Supreme Court and the past and current administrations' capacity to convene a moratorium on the raids, deportations, and detentions, the US government's response to the division of thousands of families is to continue incarcerating them and expanding enforcement-only policies such as Secure Communities, which counterpoises President Obama's promise to Latino audiences and Immigrant Rights Movement organizers that he would use his executive power to cease the raids and deportations, but interestingly has yet to mention, and or denounce the detention industry. This dire situation demands far more research, especially focusing on the psychological and emotional impact it has on these children that will be enduring and have ominous implications for the range of social servants that serve this population. This study confronts that challenge by presenting to academia and the public how the consequences of these industries have plagued certain communities of color.

In this vein, I also argue that "racially-charged rhetoric" in the early 1960s and 70s served to justify "oversuppression" tactics by law enforcement in black

${ }^{2}$ Initially plagued Middle Eastern and South Asian groups by public scrutiny and hatecrimes in the immediate post 9.11 era (see Alimahomed, 2011). communities to supply "raw material" for the newlyconstructed Prison Industrial Complex being founded in upstate New York in the post-civil rights era. Since then, research has shown that prisons have been effective ultimately in failing society and ineffective in deterring crime. For example, this paper underscores McCann's (2007) assertion that "in the long run prisons are environments that fail individuals and society, as well as Herzig's (2005) postulation that these industries do what their supposed to do, "disappear and kill those who present the greatest "threats" to state power-the "poor, youth, and noncitizens." Moreover, this evidence underscores Alexander's (2012) theoretical argument that the current criminal justice system is composed of implicitly "colorblind" policies, law enforcement agencies, and related organizations that have shaped themselves into an immense "system of mass incarceration" that comprise "The New Jim Crow."

In this paper, a review of the Prison and Immigration Industrial Complexes is explored to show that the "hypercriminalization" of the black community has now been extended to the immigrant community and the consequence has been the "disappearance" of both communities from society by mass imprisonment explained theoretically by a process I contend is ethnodistillation.

\section{THEORETICAL FRAMEWORK}

Racial theoretical paradigms such as "immigrant apartheid," "ethnic cleansing," "genocide," or other theoretical traditions that aim to explain the disappearance of blacks and Latino immigrants from society must consider that these groups are not yet in the majority, which would question "apartheid" paradigms, and these groups are not yet being annihilated by other ethnic groups into extinction to preserve ethnic dominance. As such, my goal is to build a theoretical approach that considers that "empowered" blacks and Latino immigrants are being systematically eradicated from society to maintain the hegemonic order.

\section{Sociohistorical Ethnic Violence and the Hegemonic Threat}

While bigotry and prejudice have historically divided whites and peoples of color, it was generally the expansion of capitalism and discrimination by early white Anglo Saxon invaders that propelled them to the top tier of the stratification index, and maintained that position throughout US history (Aguirre \& Turner, 1995; 
Almaguer, 1994). Moreover, the dominance of white ethnic groups, especially those that embraced the Anglo Saxon "core culture," is reflected in their economic power; yet, the imposition of the white core culture led oftentimes to ethnic violence and antagonism between whites and groups that posed a threat to its economic well being, including Native Americans, blacks, ethnic whites, Asian and Latino immigrants (Feagin 2000), Mormons, and radicals (McLaughlin, 1990). Therefore, the primary goal of the white "core culture" is to maintain hegemonic dominance at not only the expense of "others," but to keep also those "others in their place." As such, in recent years xenophobic politicians coupled with organizations such as the American Legislative Exchange Council (ALEC), have tried tirelessly to "roll back the gains of the civil rights era and push for standyour-ground laws that encourage modern-day lynchings" in a "post racial society" (López, 2012: 1).

\section{Ethnocentrism and Low Intensity Conflict Doctrine}

Instead of employing overt military-style combat drills to subjugate ethnic groups, the "low intensity conflict" doctrine (LIC) engaged against "vulnerable" blacks and Latino immigrants by enjoining military and local law enforcement into paramilitary forces has risen under the noses of its initial citizen targets in Latin America, and to unsuspecting Americans in US urban cities and along the México-US border (Dunn, 1996). The initial application of LIC was to counter "revolutions" during the tumultuous 1980s in Latin America when implemented by the Reagan Administration, and used to maintain social control thereafter.

According to Dunn (1996), LIC (1) emphasizes the "internal rather than external" defense of a country, (2) emphasizes "controlling targeted civilian populations" rather than land, and (3) emphasizes the comingling of the military and police into assuming roles traditionally belonging to one another into "paramilitary" forces, all of which have negatively impacted the human and civil rights of groups of color in the US and abroad. This paper will show that LIC has impinged on the free movement of blacks and Latino immigrants by paramilitary-like local law enforcement in barrios and ghettos, and with paramilitary-like strategies along the México-US border by border patrol. In this light, incarcerated targeted groups of LIC do not necessarily produce "inmates" and or "detainees" in the academic sense; they become more distinctively, "prisoners of war."

\section{The Ethnodistillation Theoretical Approach}

The process of ethnodistillation moves to sinisterly "disappear" divergent populations, to ultimately "extract," "purify," "cleanse," "condense" and "refine" society, more specifically to "distill" it of the "hypercriminalized class" composed primarily of people of color to maintain the white dominated social order (Díaz, 2011). The ethnodistillation theoretical approach (ETA) involves the following five components, (1) financial support for a publicly funded privately-owned prison and detention industry; (2) ardent and prolonged racially-charged and or damaging rhetoric and stereotyping targeting people of color that contributes to their demoralization; (3) a concerted effort by federal powers to form and launch legislative policies targeting groups of color to ensure lengthier periods of their disappearance; (4) local law enforcement agencies targeting groups of color by enforcing local and regionalized policies that make them vulnerable to exposure to the criminal justice system, and (5) as a culmination of the preceding components, whether it is intentional or not, is the protection and maintenance of the dominant white hegemonic order in the US.

In sum, these theoretical tenets of the ETA explore the xenophobic stereotypes that have worked concomitantly with local, regional, statewide, and federal legislation policies to set the stage for the mass imprisonment of blacks and immigrants, and have also served to fuel the Prison Industrial Complex (PIC) and the Immigration Industrial Complex (IIC), both of which serve to sustain the racial, political and economic stratified order in the US with whites comfortably positioned still at the crest. Taken together, these tenets explored below will provide ample evidence to support the contention that likewise to the PIC that succeeded in disappearing "empowered blacks from society in the post Civil Rights Movement era," the same model is now engaged to disappear Latino immigrants that are the next political, economic, and demographic threat by way of the mid-21st century's "Browning of America," when Latinos will become the demographically dominant group, thus threatening the longstanding white hegemonic order.

\section{The Latino Threat}

The increase of the Latino population is most threatening to the white hegemonic order, according to Ceasar "...ethnic and racial minorities will become the majority in the US by 2050 and that is about 1 in 3 US residents will be Latino by then" (2). While Latino 
immigration is responsible for some of the growth, recent data shows a "surge in US births" to Latinos, indicating a growing generational shift in which "they will continue to gain political clout" (Ceasar, 2011). The threat of surrendering demographic, political, and economic dominance is then fearful to whites, especially in the recent decade when their population increased only $1 \%$ from 196.6 million to 196.8 million, but their proportion of the total US population declined from $69 \%$ to $64 \%$ due to a growth in the black population to almost $14 \%$ of the US population. Similarly, Latinos surpassed 50 million individuals, which was a $43 \%$ increase in the last decade that translates to roughly 1 in 6 Americans, along with a boost in under 18-year-old Latinos from $17 \%$ in 2000 to $23 \%$ in 2010 (Ceasar, 2011). This paper demonstrates that one successful instrument in obstructing this course of action has been mass imprisonment.

\section{MASS IMPRISONMENT}

I argue next that mass incarceration in the US has served but one elemental purpose and therefore is the primary component of the ethnodistillation process, "disappearing" people of color for vast profits. Many Americans still believe overwhelmingly that mass incarceration, expanding the penal system, and growing the infrastructure that fuels and sustains it, are still the remedy for crime (Roth, 2011).

\section{A Snapshot of Mass Incarceration and the Black Experience in the United States}

In terms of the PIC and the threat that blacks posed to the hegemonic order was most relevant in the postCivil Rights Movement era and how that threat was dealt with was to incarcerate as many blacks as possible (Alexander, 2012), and it was successfuldespite their comprising approximately $14 \%$ of the total US population, half of all prisoners in the US are black, (McCann, 2007), a number 8 times greater than in the 1970s when there were 133,226 blacks in prison (Savive, 2012). Savive reported that in December 2005, there were 2,193,798 inmates in the US (737 per 100,000 residents), more than in any other country on earth. The 2 million inmate milestone was surpassed in 2000 .

Herzing (2005) posed that the PIC consists of "prisons, criminalization, media, courts and policing," giving the impression it is designed to provide safety for communities, but to the contrary argued it "does what it is supposed to do"-disappear and kill those who present the greatest threats to state power-the "poor, youth, and noncitizens." Herzing further pointed out that the PIC requires "raw materials," or prisoners, in order to preserve itself despite the ebb and flow of crime rates. McCann (2007) asserted that the PIC has sociohistorical roots tracing back to slavery, which "produce and reproduce" egregious narratives and practices regarding racial discrimination; in general, people of color, particularly juveniles, are more likely to be apprehended by law enforcement, put in juvenile facilities, and imprisoned than are their white counterparts that commit similar crimes.

More critically, McCann (2007) asserted that in the long run prisons are environments that fail individuals and society, and noted that the rise of the PIC coincided with, and according to some scholars may have caused the pointless decline in America's public educational system. As part of this trend, California spent more money on its prisons $(9.4 \%)$ than on its universities and colleges combined (8.7\%) in 1997. Subsequently, Petit and Western (2004) posited that the lifetime risks of imprisonment for black and white men differed in terms of level of education, nearly $60 \%$ of black high school dropouts born between 1965 and 1969 were imprisoned by 1999, and noncollege black men born in the late 1960s experienced a higher risk of imprisonment than death. Now consider the average cost of $\$ 22,650$ per year for incarcerating mostly nonviolent prisoners, with some "supermax" prisons costing nearly $\$ 40,000$ a year per inmate; expenditures to maintain state prisons alone ballooned to over $\$ 38.2$ billion in 2003 from $\$ 15.6$ billion in 1986, the year the "War on Drugs" was formally legislated (McCann, 2007). Despite the enormous costs to the American public, there are social and psychological costs to the detainees as well.

The PIC's toxic effects on democracy are tied directly to the electoral process. An estimated 4.7 million Americans lost the right to vote because of exclusionary laws in 48 states that disenfranchise the imprisoned, and in 36 states where former inmates on parole or probation a barred from voting (McCann, 2007). As a result, in 1998 as many as 1.5 million black males were denied the right to vote; that number that has surely grown since then. Seen in this light, the PIC reproduces the worst electoral racism since the Jim Crow-era "poll tax." To paint a picture of individuals that had become vulnerable to losing their voting muscle, Pettit and Western (2004) reported that between 1974 and 1999 the percentage of men entering prison for the first time grew substantially and the percentage of 
inmates more than doubled; and, among men born between 1965 and 1969, 3\% of whites and 20\% of blacks had served time in prison by their early $30 \mathrm{~s}$. The pair argued that the rise of mass incarceration is a new stage in the life course of young low-skilled black men, and unfairly impacts certain groups over others. As such, by mid2006, 409 per 100,000 white, 1,038 per 100,000 Latino, and 2,468 per 100,000 black inmates comprised the nation's prison population, showing that "...incarceration is not an equal opportunity punishment" (Savive, 2012). The disparities against people of color are so embedded in the PIC, it functions as a well-oiled machine of racial injustice powering an incarceration nation

Savive (2012) put forth that when males between 25 and 29 years old are highlighted, white inmates comprised 1,685 per 100,000, Latino inmates 3,912 per 100,000 , and black inmates 11,695 per 100,000 , which totaled $11.7 \%$ of black men in their mid-to-late $20 \mathrm{~s}$. In comparison, in 1993 under South African Apartheid black inmates comprised 851 per 100,000; and in 2006 under the "leader of the free world," President George W Bush, 4,789 per 100,000 blacks were incarcerated at a rate 5.8 times higher than the most openly racist country in the world (Savive, 2012). On the homefront, Hartney and Glesmann (2012) asserted that the 1980s "get-tough-on-crime" policies were the precursor to spiking incarceration rates and "private detention centers" that housed 128,195 of the 1.6 million state and federal inmates in 2010. The pair of authors claimed there were 33,830 in private federal facilities and 94,365 in private state facilities, a rise from just over $3 \%$ in 1995 to $8 \%$ in 2010 . To put these numbers in context, there are more blacks in prison now, than there were slaves in the decade leading up to the Civil War.

\section{A Snapshot of Mass Incarceration and the Immigrant Experience in the United States}

The number of inmates of color does not fully tell the whole story, immigrants are more often being held in county jails and prisons across the country (Fernándes, 2007), and the enforcement of federal antiimmigrant policies that fuel the growing imprisonment of immigrants is quite distinct than that for US-born people of color, especially in relation to the escalating major workplace ICE raids, deportations, and detentions in response to the 2006 megamobilizations entrenched still in the minds of citizens and noncitizens (Díaz, 2010). Though researching immigrant detention centers has grown, they are not a new phenomenon; they were established throughout the US in the $20^{\text {th }}$ century. In his seminal work on the Mexican "wetback," Samora (1971) researched three along the México-US border in El Centro, CA, and EI Paso and Los Fresnos, TX. In New York City centers were established in the 1970s and 80 s that dealt with the influx of Cuban and Haitian refugees before the industry expanded into Georgia in the late 1980s. Initially the industry was operated by INS until private profiteers founded the first Texas center in the 1980s by the Correctional Corporation of America (CCA).

ICE detainees tripled from 7,444 in 1994 to approximately 23,000 in 1996, while the Marshals Service's prison population doubled to an estimated 63,000, which houses citizens and noncitizens (Wilder, 2006), and from 1997 to 2007 detention rates more than doubled (Douglas \& Saenz, 2009). Detainment has increased by $31 \%$ in the past ten years, and among undocumented immigrants from all nationalities detentions exploded from 6,785 in 1995 to more than 22,000 in 2006, while the US Government was paying the private prison profiteers $\$ 95$ a head in 2007 (Lydersen, 2007). Detentions more than tripled from 5,532 in 1994 to 19,533 in 2001; and in fiscal year 2000 INS detained more than 188,000 impermissible immigrants (Department of Homeland Security, 2009; Jackson Lee, 2001).

By 2006, Congress had authorized the development of 40,000 new ICE beds over the next five years, and 4 to 5,000 for the Marshals Service (Wilder, 2006). Wilder further reported that in the 2007 budget President Bush proposed a $\$ 452$ million increase in ICE funding for another 6,700 beds, and as part of his contribution to the government's building-and privatizing - binge, KBR, a Halliburton subsidiary, was awarded a contract worth up to $\$ 385$ million to build temporary immigrant detention facilities for DHS in case of an "emergency influx of immigrants" (2). The 6,700 new ICE detention beds represented an additional 134,000 people per year to be processed through the system. The top companies in IIC are the Corrections Corporation of America (CCA), GEO Group Inc., and Emerald Correctional Management, that according to the US Government Accounting Office, are paid pay $\$ 750$ million annually by taxpayers to house 18,000 undocumented immigrants in California prisons alone (Boudreaux, 2006).

In 2009, ICE averaged approximately 32,606 inmates per day; about half of these detainees were 
housed in one of more than 400 minimum- or mediumsecurity private facilities that averaged daily populations of 500 inmates or less (Hartney \& Glesmann, 2012). Now, it is estimated that " $80 \%$ of ICE's beds are rented at 300 local and state jails nationwide, concentrated in the South and Southwest" (Hsu \& Moreno, 2007), and of those detainees filling the beds $90 \%$ were from Latin America, 62\% México, $25 \%$ Central America, and 3\% from the Caribbean (Department of Homeland Security, 2009). By the end of fiscal year 2009, ICE detained 380, 000 individuals from 221 countries. Subsequently, Rosetta Stone, the language-learning provider entered a $\$ 775,000$ threeyear contract with ICE, to offer 15,000 agents instruction in 30 languages to tackle mostly Spanish and Arabic linguistic barriers (Kang, 2007). This was a new direction by ICE which has actively targeted mostly Latino Spanish-speaking agents to operate detention centers and patrol the border.

Detention negatively affects detainees' lives while they await deportation and or asylum hearings. Ironically, detainees have hitherto not been convicted of crimes, yet are held in prisons that restrict their movement, prevent access to gainful employment, and most detrimentally limit interaction with their families and society, both of whom are greatly dependent on them. On average, detainees are kept in detention centers 370 miles from their families. As a result, detentions insidiously cajole parents and oftentimes their children into a situation that makes it virtually impossible to survive on single or nonexistent incomes. Even more psychologically and emotionally damaging to detainees' well being is that an estimated 5 million children in the US have at least one undocumented parent, and 1.8 million are themselves undocumented thus making them vulnerable for detention. More concretely, in the first half of 2011, 46,686 parents with at least one US-born child were deported, and by January 2012 an estimated 5,100 children were in fostercare-another 15,000 will be in fostercare if this rate continues (Wessler, 2011).

Three years ago, on a daily average 30,000 immigrants were in detention awaiting hearings, rendering private contractors $\$ 200$ a head per day for family detention in one of three "family friendly" centers since 2004 when Congress also passed legislation authorizing ICE to triple its number of detention bedsCCA's lobbying expenditures reached $\$ 3$ million during that campaign, and in the next five years it spent $\$ 7$ million more on lobbyists (Martin, 2009). Contrariwise, the transition from "catch and release" to "catch and detain" is riddled with controversy because before 9.11 families seeking asylum and or charged with immigration violations-that are not criminallynatured-were released on their own recognizance with a mere $6 \%$ failure to appear record. This is ironic because before the events of 9.11 the detention industry was economically failing, but boomed under the Bush Administration, which armed ICE with a \$1 billion-plus detention budget immediately following 9.11 (Golash-Boza, 2009a). Overall, the figures presented here are all expected to rise because Congress now requires the Obama Administration in general, and ICE in particular, to detain and deport a minimum 400,000 immigrants per year- ICE's funding depends on meeting that quota (Gavett, 2011).

\section{STEREOTYPING}

The next discussion of a major tenet relative to the ethnodistillation process is the exploitation of stereotypical images to understand better how blacks and immigrants are stereotyped in the media and how they have been used to justify their removal from society. More specifically, examples from the entertainment and journalism industries are presented here to show how they have been "hypercriminalized" in public discourse, which has made them vulnerable for mass imprisonment.

\section{Stereotyping Blacks}

The stereotypical images of "crackhead," "drug dealer," "gangbanger," "street criminal," "street worker," "welfare queen," have prevailed in portraying the black experience in customarily socioeconomically-ravaged communities. Some of these images demoralized blacks during and after the Civil Rights Movement by the Blaxploitation film industry, a digression from the stereotypical passive roles that fraught early cinematic history (Horton, Price \& Brown; 1999). In the post Civil Rights Movement, blacks were empowered by their political victories, and on the big screen by images reflecting the "black reality" of being an "underdog" protagonist, especially one that could "give it to the man, the white establishment," particularly through violence, which was the unique formula of the industry's success (Allen, 1999). Allen branded the protagonist heroes as typical "...everyday Joespeople who would normally be condemned in society because they were also pimps, drug dealers, pushers, informers and prostitutes...The result of the exaggeration and sensationalism was the articulation of 
stereotypes that were far from depicting the true black experience or values" (1999: 4).

Through mostly white producers and directors, misconceptions and generalizations infiltrated the industry, subsequently the black cinematic images were more of a white perception of the black community, and the misrepresentations redefined new stereotypes and generalizations of blacks that persist on and off the silver screen especially related to "drugs and gangs" (Allen, 1999), and now as superpredators (Oboler, 2009). In following years, black actors, actresses, and filmmakers portrayed predominantly the "gangster in South Central" and "corrupt" authoritative positions, which has served them well in terms of award winning ${ }^{3}$. Horton, Price and Brown (1999) posited that although most black filmmakers believed they were helping the black community by exposing its faults and showing them in a better way, because of the large crossover audience they only contributed to the dominant negative stereotypes of "laziness and violence," which has translated into the moral detriment and lack of positive images of the black community in the media. There continues to be a thin veil separating public perception, cultural stereotyping, and policymaking especially in the media's perpetuation of racialized "criminal imagery."

According to Alexander (2012), during the post Civil Rights Movement the population of youth along with black male unemployment and national crime rate were rising sharply, making them ripe for the media to lump together and sensationalize "....as further evidence of the breakdown in lawfulness, morality, and social stability in the wake of the Civil Rights Movement" (41). To make matters worse, the riots and a series of uprisings that swept the nation following the assassination of Martin Luther King, Jr. translated into a "racial imagery" associated with the unrest that fueled the argument that "civil rights for blacks led to rampant crime." It also opened a window of opportunity for xenophobic conservatives to remind cities where unrest had unfolded such as Philadelphia and Rochester, that because they had been so generous in "...having

\footnotetext{
${ }^{3}$ Denzel Washington won an Oscar for his 2001 film Training Day, and Halle Berry won also an Oscar for her 2001 film Monster's Ball. Washington had only won an Oscar for best supporting actor for his 1989 film Glory, for his role as a bitter slave turned "good" soldier in the Civil War drama. Until he played a "corrupt" cop that terrorizes "criminals" of color in LA's ghettos and barrios in Training Day and finally killed by "white terrorists," he won the top prize, and until Berry hooked up with a racist prison guard that had executed her life partner on death row did she win the top prize. These roles were out of broad character for the pair, and therefore questionable if they had not played these "stereotypical roles," would they have won Oscars.
}

welcomed blacks migrating from the South," they had been "repaid with crime-ridden slums and black discontentment" (Alexander, 2012: 42).

Horton, Price and Brown (1999) postulated that for many Americans the media sets the tone for their "morals, values, and images of our culture," some of them have "never encountered black people," and still believe that the "degrading stereotypes of blacks" are oftentimes based on "what they see on television," or "moviemaking," which "...making these horrible stereotypes continue to plague us today, and until negative images of blacks are extinguished from the media, blacks will be regarded as second-class citizens" (2). As such, the effort against negative stereotypical imagery amongst Americans toward blacks could be perceived as unreasonable and or unattainable based also on early research that demonstrated white and black preschoolers favored their lighter phenotypic counterparts over darker ones (Clark \& Clark, 1940), and similar research decades later wherein both white and black groups chose a "white doll" over a "black doll" (Powell-Hopson \& Hopson, 1988). However, Powell-Hopson and Hopson showed that racial preferences among children could be altered at least temporarily when it was revealed that in a posttest analysis with positive imagery, a significant percentage of preschoolers chose a "black doll," and argued then that "scientists and clinicians have the tools to foster development of healthy positive self-images in youth," especially amongst black children.

Despite the research that showed promise during that epoch, the barefaced "welfare and crime-related" stereotypes of blacks in the post Civil Rights Movement era were especially imperative to purge in the general excision of racial discourse in then Governor Ronald Reagan's presidential campaign (Alexander, 2012). Alexander posited that Reagan was able to build off of his predecessors and condemn "welfare queens" and criminal "predators" with the support of "poor and working-class whites," which allowed the path to be paved for the "War on Drugs," and supplementary policies that guaranteed and continue the mass imprisonment of blacks.

\section{Stereotyping Immigrants}

A parallel prototype has developed for mostly Latino immigrants, stereotyping them from "alien" to "criminal alien," that is from an "other" amongst us, to a "criminally-active other" amongst. Stereotyping 
immigrants, whether it is targeting Muslim communities or Latinos as criminals has led to a widespread and heightened vigilance to monitor their activities, restrict their movement, and ultimately remove them from society by imprisoning them (Díaz, 2011; Fernándes, 2007), which has also involved LIC and realigning a unilateral "drug war" to a broad "Border War" (Kil \& Menjívar, 2007). Although the Latino and Arab American immigrant experiences are distinct in many ways, both groups have had to endure a "culture of fear" that has ingrained itself into US society that has encouraged the stereotyping of all immigrants from all backgrounds as "terrorists" (Alimahomed, 2011), a structural paradigm that serves to justify controlling and imprisoning them, as such the LIC doctrine is especially relevant when applying its "internal rather than external focus" (Dunn, 1996), and increasingly reaching far beyond US international borders.

Recently, DHS Secretary Janet Napolitano admitted the US expanded its use of "surveillance drones" on America's borders, and also that flying unmanned aerial aircraft inside the US is the next step to ensuring "public safety" (RT America, 2012). If the issue of "public safety" depends on identifying "criminals" from 60,000 feet above earth, and the labeling of immigrants as "criminal aliens" persists, there is no doubt that the infringement of their civil and human rights will transpire first in this next technological stage of the LIC struggle they have confronted for decades. Though these and countless other stereotypes of immigrants permeate society, it is the unpredictable and unfounded "threat to national security" that has gained the most traction (Díaz, 2011).

The debate between whether or not journalists should restrain the term "illegal" from public domain is the necessary first step to eliminate the loaded and derogatory term that is also abusive to the psyche of the children of immigrants, which is the most concerning because "next generations" of immigrants have higher rates of crime than their first and second generation counterparts (Lee, 2003). The public education campaign to abolish the "I word" solicits individuals to commit to "value dignity" and pledge online to reject the "racially-charged slur" that confuses the national immigration debate, fuels violence," and does not "reflect the values of immigrants." Mónica Novoa, coordinator of the campaign, argued that "Getting rid of the "I word" is about our society asserting the idea that migrants are human beings deserving of respect and basic human rights" (Thompson, 2011: 4). For that reason, the campaign challenges the media to drop the stereotypical term that "dehumanizes" individuals for an "act," which is what is actually "illegal," because "No Human Being Is Illegal!" In response, Novoa remarked about her disappointment to otherwise sensitive journalists who continue to employ the "I word," which "points to how normalized the language has become" (Thompson, 2011).

Another stereotype that has taken hold is the "drug smuggling" stereotype, which has been used by top Arizonan politicians to push unfounded claims discussed below, but has especially grown in the public vilification of immigrants by antiimmigrant zealots such as Barbara Coe, founder of the California Coalition for Immigration Reform, who at a 2005 rally declared "...every immigrant caught at the border would be one less illegal alien bringing in communicable diseases, one less illegal alien smuggling deadly drugs, one less illegal alien gang member to rob, rape and murder innocent US citizens" (One People's Project, 2005). A year later, vigilante Chris Simcox, of the Minutemen, a racist antiimmigrant hategroup ${ }^{4}$ that reached infamy by patrolling the México-US border in April 2005, chimed in stating, "They have no problem slitting your throat and taking your money or selling drugs to your kids or raping your daughter and they are evil people."

In the same period, a Texas A\&M Republican student group invited Texas vigilante Sandra Beene to a immigration forum where she reaffirmed the pathological stereotype of "Disease-carrying bordercrossing Mexican," she spoke about "...shooting varmints and about how ranchers used to shoot cattle that crossed the border for fear they might have diseases...[and] now, we're bringing all the diseases that we wiped out right back in" (Kennedy, 2006: 2). Later, Beene made another comment that intersected the black and immigrant struggles, "Once, in this country, we imported a lot of people who were black, and we created a slave class of human beings, and we're still paying for that, through all the resentment. And black people are still paying for it, too" (Kennedy, 2006: 2). There is little doubt that the goal of this strain of vigilante is to "cleanse" our country of any sociohistorical evidence of people of color, and would justify by any means wiping away any inkling of diversity to maintain white superiority. By "protecting"

\footnotetext{
${ }^{4}$ The Minutmen have been identified and documented by the Southern Poverty Law Center, along with the California Coalition for Immigration Reform, as hategroups.
} 
the México-US border, while leaving "unprotected" the Canadian-US border, is evidence enough of their actual agenda, to "protect" the hierarchical "racial order."

\section{SOCIOHISTORICAL POLICYMAKING}

Another component of the ethnodistillation process is federal level policymaking such as the "War on Drugs," which implored a "get-tough-on-crime" consciousness that have captivated the American public while filling the pockets of private prison profiteers that have lobbied to expand the Prison and Immigration Industrial Complexes. In this section, similar policies that have sociohistorically "criminalized" people of color in the US are reviewed.

\section{The Sociohistorical Trend of Legislation that has Criminalized People of Color}

Slavery is one of the most atrocious acts of violence ever accepted in the US, but it is important to remember that in the colonies it was "legal," bounded by "slave codes" initiated in the mid-1600s. Indentured servitude transformed into an ideal source of enslaved labor. It became quickly evident that servants who would become "free in a set number of years" were not as cost effective as investing in slaves that would "last a lifetime" (Farlex, 2008). These were the first of many policies that have been detrimental to blacks in the US, but it was the policies of resisting slavery that criminalized blacks and swiftly increased. In the words of Harding (1981), it becomes clearer that policies against blacks have evolved in many forms and continue to plague them to the present,

Beginning in Virginia at 1630s, laws establishing lifelong African slavery were instituted. They were followed by laws prohibiting black-white intermarriage, laws against the ownership of property by Africans, laws denying blacks all basic political rights...In addition, there were laws against the education of Africans, laws against the assembling of Africans, laws against the ownership of weapons by Africans, laws perpetuating the slavery of their parents to African children, laws forbidding Africans to raise their hands against whites even in self-defense...[The laws] outlawed many rituals connected with African religious practices, including dancing and the use of drums. In many places they also banned African languages. Thus they attempted to shut black people out from both cultures, to make them wholly dependent neuters (Harding, 1981: 27).

Harding's words give a clear picture of the black struggle in the US, and call to question the sexual and gender discrimination blacks experienced, along with the attacks on their voting rights, affirmative action, cultural traditions, and unequal distribution of "stand your ground" laws, etc., all of which evolved into varieties of struggles that exist even in the present.

Following the abolishment of slavery were years of policy-justified discrimination and isolation of blacks in the form of segregation. Resisting together, black and white workers overcame this racism briefly during the post-Civil War Reconstructionist era, when they organized side by side in the quest for better wages and conditions in the South, but it was the Jim Crow laws that were quickly ushered in to divide and conquer them when that unity threatened the Southern elite (Alexander, 2012). Even though the Jim Crow system was eventually dismantled by the impressive legislative victories of the Civil Rights Movement (McAdam, 1982), the white ruling class successfully framed the Movement's peaceful demonstrations and acts of civil disobedience as a breach of "law and order," and used the rise of crime during the 1960s to further support its position (Eitzin \& Baca Zinn, 2007). Sociologists and Criminologists agree that crime rates did ascent, but was related more to the spike of "baby boomers" in the 15 to 24 year old age group, a group that has historically been responsible for committing the most crime (Alexander, 2012).

The effort to undermine the empowerment of blacks at the height of the Civil Rights Movement era successfully set the tone when it pioneered criminallycharged racial discourse. Moreover, Alexander (2012) claimed that DC desegregationists utilized "racially sanitized rhetoric," to argue that the civil rights legislation was "bending over backwards for criminals," and eventually initiated the phrase "cracking down on crime," which is used still by politicians of all stripes to fight "crime on the streets" (42-43). Along with the gains of the Civil Rights Movement came backlash on predominantly urban blacks in New York City. For instance, the Harlem activist community openly resisted the upsurge of police activity and abuse in their community, while others in the community demanded "law and order" (Alexander, 2012). 
Conservatives pointed to the demand to undermine the charge of "racism" at the hands of NYPD and to support their agenda for more punitive laws and longer sentences they finally legislated in what became "Rockefeller Drug Laws," named after New York Governor Nelson Rockefeller.

The "Drug Laws" in New York immediately followed President Richard Nixon's "War on Drugs" declaration in June 1971, when he dramatically escalated the size and presence of federal drug control agencies, pushed through mandatory sentencing and no-knock warrants, and put Marijuana in the most "restrictive category," and appointed in 1972 commission that unanimously recommended decriminalizing the possession and distribution of marijuana for personal use, but ignored and rejected its report and recommendations (Drug Policy Alliance, 2012). According to the Alliance, between 1973 and 1977, eleven states decriminalized Marijuana possession, and in 1977 under the President Jimmy Carter Administration whose campaign platform included Marijuana decriminalization, the Senate voted to decriminalize possession of up to an ounce of Marijuana for personal use. The Rockefeller Drug Laws were supposed to fight the "popularity and rise in recreational drugs sweeping the nation," by offering alternatives such as probation and parole, "militarystyle camps," jails, and drug rehabilitation ( $\$ 15,000$ per stay), which would save the state millions of dollars in prison stints costing up to $\$ 45,000$ per year (Roth, 2011). Though crime-fighting politicians had good intentions, the laws proved to be ineffective in curbing drug abuse, but served to grow the prison population.

In 1973, demands for harsher penalties had "grown too loud to ignore," prompting the enactment of mandatory minimum sentences of 15 years to life for possession of four ounces of narcotics-the same as for second-degree murder (Gray, 2009). The "Drug Laws" immediately led to an increase in drug convictions, but no measurable decrease in overall crime, essentially they "...criminalized what was primarily a public health problem, incarcerated nonviolent felons who were better off in treatment, caused a jump in recidivism rates, and prevented judges from using discretion in sentencing" (Gray, 2009: 1). Drug offenders in New York's prisons surged from $11 \%$ in 1973 to $35 \%$ in 1994 , yet $16 \%$ had a history of violence (Gray, 2009). By 1979, the "Drug Laws" were amended to reduce penalties for Marijuana possession. In a State of the State address, New York Governor David Paterson commented on the failed policies stating "I can't think of a criminal justice strategy that was more unsuccessful than the Rockefeller Drug Laws."

Given the disappointment of the "Drug Laws," it is remarkable that the conventional "War on Drugs" was launched in later years on such an ambitious level. On October $27^{\text {th }}, 1986$, the Reagan Administration passed the Anti-Drug Abuse Act with a $\$ 1.7$ billion budget, $\$ 200$ million for education, $\$ 241$ million for treatment, and $\$ 97$ million to build new prisons (Frontline, 2012). Largely due to media portrayals of a "crack epidemic," and First Lady Nancy Reagan's highly-publicized antidrug campaign slogan "Just Say No," set the stage for the "zero tolerance policies" trend (Drug Policy Alliance, 2012a). There is no doubt the media was key in igniting the drug war. In 1985, just 2 to $6 \%$ of Americans perceived drug abuse as the nation's "number one problem," by 1989 the figure reached a remarkable $64 \%$ - one of the most intense fixations by the American public on any issue in polling history (Drug Policy Alliance, 2012a). As the media lost interest, that figure plummeted to less than $10 \%$ within less than a year.

America's "War on Drug" policies have greatly contributed to eradicate black males from society in the transformation from "Welfare State to Security State." The Anti-Drug Abuse Act required federal judges to give "fixed sentences" to drug offenders based on the "amount of narcotics" seized and the "presence of firearms," and prescribed a 5 year sentence for a firsttime offense of distributing five grams of crack (two sugar packets), while possessing 500 grams of powder cocaine carried the same sentence-possession of at least one kilogram of heroin, or five kilograms of cocaine, rendered 10 years in prison (Frontline, 2012). These "mandatory minimums" were criticized for promoting racial disparities amongst inmates because whites are associated more with "powder cocaine," whereas blacks are associated more with "crack cocaine," making them more susceptible to lengthier sentences. Notoriously, President Bill Clinton rejected a US Sentencing Commission recommendation to eliminate the disparity between crack and powder cocaine sentences, even though he told Rolling Stone Magazine on his way out of office that Marijuana "should be decriminalized" (Drug Policy Alliance, 2012a).

Needless to say, the Reagan Administration prolonged skyrocketing rates of incarceration, thanks largely to his unprecedented expansion of the drug war, which put 50,000 nonviolent drug law offenders 
behind bars in 1980 to over 400,000 in 1997; furthermore, 1980, drug offending inmates represent an $1100 \%$ increase to over 500,000 today, and in 2005 , blacks represented $12 \%$ of all drug users, and $45 \%$ of those in state prisons for drug offenses (Mauer, 2009). The draconian policies enacted during the hysteric years of Reagan's Administration, continued to produce escalating levels of arrests and incarceration well into the Clinton Administration. Although during his 1992 presidential campaign he advocated for "treatment instead of incarceration," after a few months in office he embraced the "drug war strategies of his Republican predecessors" by escalating the drug war (Drug Policy Alliance, 2012a). All in all the "War on Drugs" has become an inane policy that has succeeded only to incarcerate 1,638,846 nonviolent offenders in 2010, and now costs American taxpayers an average $\$ 51$ billion per year-money better invested in a "War on a Health Problem" not prison construction.

\section{The Misrepresentations between Black and White Propensities for Crime and Policy}

According to federal studies, blacks and Latinos are searched and arrested more often during routine traffic stops than are whites. In 2002 and 2007, the Bureau of Justice Statistics found that police threatened and or used force against blacks and Latinos more than against whites in any type of encounter, including routine traffic stops (Savive, 2012). Savive reported that racial profiling has also proven to be ineffective in the "War on Drugs." In 1999, the US Department of Justice revealed that officers attempting to interdict drug transporters found drugs more often concealed on whites (17\%) than on blacks (8\%), similarly New Jersey state troopers found drugs in vehicles driven by whites $25 \%$ of the time, blacks $13 \%$ of the time, and Latinos $5 \%$ of the time (Savive, 2012). Moreover, the US Department of Health and Human Services, found that young white adults between 18 and 25 years old ingest marijuana more than their black peers, yet they are arrested for marijuana usage at a much lower rate than blacks; for example, another 2010 report found that in California's biggest cities blacks were arrested for possession at four, five, and even 13 times the rate of whites (Savive, 2012).

Savive (2012) concluded that most citizens expect law enforcement to conduct themselves ethically, therefore by racial profiling officers engage in "unethical, immoral, and unconstitutional behavior," which calls attention to the LIC doctrine that puts forth the disregard for human and or civil rights. Overall, research on the racial biases of the criminal justice system shows blacks in the US are three times more likely than whites to be arrested and ten times more likely to be jailed for drugs, and even more disturbing is the lack of evidence showing that blacks use or deal drugs more than their white counterparts-making the "War on Drugs" seem more like a "War on blacks" (Savive, 2012). The same is similar to the immigrant experience, while they are labeled and misrepresented in the media as "criminals," they report the lowest rates of crime than their US-born counterparts.

\section{The Sociohistorical Trend of Legislation that has Criminalized Immigrants}

Immigrants have consistently experienced "restrictive" immigration policies couched in xenophobia such as the serial exclusion of Asian immigrants during the "yellow peril," an epoch prohibiting Chinese in the Chinese Exclusion Act 1882, and the 1882 Immigration Act that also targeted drug addicts and sex workers; the Japanese in the 1908 Gentleman's Agreement that was not formally ratified and or manifestly law; Filipinos in the Immigration Act of 1917 that excluded also "Asian Indians and all other native inhabitants of a barred Asiatic zone from Afghanistan to the Pacific" (Ngai 2004: 18). Restrictive policies soon included the expulsion of immigrants, especially Mexicano immigrants when they were no longer wanted for their labors (Samora, 1977). The Johnson Reed Act of 1924 implemented the Immigration Nationalization Service (INS) to patrol the México-US border mostly to apprehend Chinese and European immigrants, and also Mexicano workers breaching binational labor policies (García, 1994).

In the 1930s, the INS conducted "repatriation drives" throughout the Southwest that were riddled with human and civil rights violations, resulting in 80,000 deportees that were officially encouraged to leave the US by local authorities emboldened by the prevailing Jim Crow system in their segregated jurisdictions (Dunn, 1996). The McCarren-Walter Act 1952, "criminalized" immigrants even before they embarked upon their trek to the US for being "communist" and or "subversive." Akers Chacón (2006) postulated the policy forged at the height of MyCarthyism targeted the "...lax attitude of the government toward illegal immigration," and "felonized anyone that imported or harbored" an undocumented immigrant, but interestingly vindicated anyone that employed them, conditions that simplified labeling immigrant workers to have them "removed." This policy also set the stage for 
Operation Wetback in 1954, which was an INS paramilitary campaign that resulted in the deportation of well over a million Méxican workers and their families (Vogel, 2007). Despite the expulsions, during the second half of the $20^{\text {th }}$ century, the demand for Mexican workers continued to rise to an annual average of 430,000 workers a year (Vogel, 2007).

In response, the 1965 Immigration Act welcomed millions of immigrants from Asia and Latin America, however for the first time a quota system was initiated the mass criminalization of Asian and Latino immigrants coming impermissibly into the US and or exceeding their country's quota (Massey, 1995; Massey, Durand \& Malone, 2002). By default, it also created the "undocumented Mexican," and set the stage for a new "War on the Border." In comparison to the ambitious War on Drugs era when black males experienced the brunt of imprisonments at its onset, immigrants were also targeted by President Ronald Reagan who implemented the Alien Criminal Apprehension Program in 1986, which added more resources to locate and deport immigrants in custody (Fernándes, 2007). The move to put "INS holds" on incarcerated immigrants for nonimmigration-related issues coincided with the surge of northbound immigrants, while also playing into the hands of bigoted hategroups forging an antiimmigrant movement in California led by characters like Barbara Coe (Suro, 1996), whose depraved antiimmigrant comments were presented above. The antiimmigrant movement had grown since the early 1970s, but reignited after the 1986 Immigration Reform and Control Act granted amnesty to millions of immigrants in the US, but instituted "employer sanctions" that unlike the McCarren-Walter Act granted employers the liberty to hire undocumented workers (Díaz, 2010).

In 1994, California Proposition 187 proponents sought to refuse social services to undocumented immigrants, conveying to immigrants they were unwanted and would not be assisted, and if they sought assistance they would be reported to INS by social servants that would become federal immigration officials by default (DeSipio, 1996). Voters passed 187, but after mass proimmigrant mobilizations across the state it was found to be unconstitutional in the courts (Acuña, 1997; Díaz, 2010). The 1996 Illegal Immigration Reform and Immigrant Responsibility Act (IIRIRA) immediately made-in retrospect"permanent residents" vulnerable for deportation for past "minor offenses" that instantaneously became "aggravated felonies" (Reese \& Ramírez, 2002). At least 500 legal "permanent residents" were detained after having paid their "dues to society" for erstwhile DUls, hence making these individuals felons and automatically subject to deportation and or detention (Akers Chacón \& Davis, 2006). Although the routine of deportations had been instrumental in targeting immigrants, the trend to hold them "prisoners of war" quickly became the preferred "order of the day."

In 2003, the program "Endgame" was implemented by the Office of Detention and Removal, a subagency of ICE, to over a decade "remove all removable aliens by 2012 ," specifically to deport primarily the " 590,000 people who had ignored deportation orders" and 630,000 "criminal aliens" serving sentences in jail or prison (Wilder, 2006), a throwback to the 1986 Alien Criminal Apprehension Program. However, the most draconian antiimmigration policy was HR4437, which passed December $16^{\text {th }}, 2005$, in the House of Representatives, but stalled in the Senate would have (1) immediately "felonized" 12 million undocumented immigrants and (2) charged anyone that aided and abetted them with an aggravated felony, (3) authorized local law enforcement officers to enforce federal immigration laws, (4) constructed 700 hundred miles of fencing along the México-US border, and (5) called for the immediate deportation of all unauthorized and deportable immigrants (Díaz, 2011). To ensure the bill's demise, the immigrant rights community organized megamobilizations during La Gran Epoca Primavera 2006 (Díaz, 2010), since then immigrants have struggled with local and regional "enforcement only" policies that fuel the Immigration Industrial Complexensuring their mass imprisonment.

Derived from IIRIRA were the 287G, EVerify, No Match Letters, and Secure Communities programs that were initiated by the Bush Administration following the megamobilizations in spring 2006, and continued into the Obama Administration. According to the immigrant rights community in Los Ángeles, President Obama "promised immigration reform" to Latinos but instead dealt them "fierce repression" via EVerify workplace "I9 audits" during "electronic raids" (Southern California Immigration Coalition, 2009). Since EVerify's inception, immigrant workers' records are digitized and linked to ICE's fingerprint database, causing the "termination of tens of thousands of workers across the country." The No Match Letters Program scrutinizes the social security numbers of workers during "office raids." The 287G Program relinquishes with no oversight, "immigration enforcement power to local law enforcement" and "corrections agencies." In 2009, 
DHS's plan to expand the program was denounced because of widespread abuse such as arresting immigrants for "fix-it tickets" and minor traffic offenses, suggesting law enforcement abused its "power" to purge immigrants by making "pretextual arrests that forcefully deport people," forcing an arrestee to give birth shackled to her bed (Detention Watch Network, 2009).

The 287G Program is "predatory and ripe for corruption and profiling" that will "harm community stability and safety for everyone," but it is the controversial Secure Communities Program that is expanding nationally. When "state and local law enforcement" arrest someone for a criminal offense, his or her fingerprints are electronically submitted to Federal Bureau of Investigation (FBI) and DHS databases to "determine criminal histories," fulfilling a "2002 Congressional mandate for the FBI to share information with ICE, and is consistent with a 2008 federal law instructing ICE to identify criminal aliens for removal" (ICE, 2009). According to ICE, if the person has been previously fingerprinted by their agency then there is a digitized record and a "match" will register determining him or her undocumented or "removable." Beyond the upsurge of "workplace raids" by the Bush Administration in response to the 2006 megamobilizations, it is important to consider that the programs resulting from the 1996 Illegal Immigration Reform and Immigrant Responsibility Act have primarily served to apprehend a quota-minimum of 400,000 immigrants and deport more than 1 million people (Gavett, 2011), while detaining approximately 380,000 individuals per year under the watch of the Obama Administration (DHS, 2009).

\section{The Misrepresentations of Immigrants' Propensities for Crime}

Despite the "criminalized" stereotypes that have plagued immigrants, there is vast research that has consistently shown that they engage in less crime than their US-born counterparts (Martinez \& Valenzuela, 2006), that has explored the trends that have shaped and or influenced the way immigrants of color have been treated in the US (Brotherton \& Kretsedemas, 2008), and what purpose the detention of immigrants serves and who it benefits (Díaz, 2011). Before immigration detentions, federal commissions at the turn of the $20^{\text {th }}$ century including the 1901 Special Report on General Statistics of Immigration and the ForeignBorn found that between $1880-1890$ as the foreignborn population went up, the rate of criminality went down (Kelsey, 1926), and that between 1850-1860 the foreign-born population in New York increased relative to the total population, but the annual average number of convictions during this period fell below the average for the preceding decade (Hourwich, 1912). The 1911 Immigration Commission (Horowitz, 2001), and a 1931 National Commission on Law Observance and Enforcement, found no link between immigration and crime (Bowler, 1931).

Decades later, studies continued to show the lack of correlation between immigration and crime (Martínez, Stowell \& Lee, 2010). For instance in 1985, FBI records reported foreign-born individuals accounted for only $19 \%$ of total arrests in six major cities, and in 1998, in cities with high and low density immigrant populations, crime remained constant from "year-to-year over 10 years" (Butcher \& Piehl, 1998a). In general, an increase in the incarceration of immigrants coincides with an overall trend showing an increase in incarceration in general (Morawetz, 2000), and data for the length of immigrant sentences may be inflated because they are given lengthier sentences than USborn individuals, better understood by the discrepancy of lengthier sentencing between offenders of color compared to white offenders (Butcher \& Piehl, 1999; Martinez 2000). Studies continue to show that immigrants commit proportionally no more than or even fewer crimes than native-born citizens, however the longer the exposure to the US, the more likely next generation immigrants are to mirror or surpass nativeborn crime rates (Butcher and Piehl, 1998b). For instance, first generation Mexicans in Chicago were 45 times less likely to commit violence than the 3rd generation (Sampson, 2006). While this research presents the absence of significant crime rates amongst immigrants, they should also underscore why mass incarcerating them in the Prison and Immigration Industrial Complexes is inane.

\section{REGIONAL AND LOCALIZED POLICIES THAT FUEL THE COMPLEXES}

Other key components in the ethnodistillation process are the local and regional policies that serve to fuel the Prison and Immigration Industrial Complexes. The examples of policies presented here are the "stop and frisk" tactic employed by the NYPD, and the federal Operation Streamline policy that is occurring on the México-US border where the lion's share of immigrant bordercrossers into the US has been unfolding for years. 


\section{Local and Regional Policies That Fuel the Broader Prison Industrial Complex}

While there are ample examples of local, regional, or statewide policies that fuel the PIC with "commoditized bodies" such as the "three-strikes" policies that have been adopted by various states, the highly controversial "stop and frisk" policy occurring across New York City is presented here as an example of a localized policy causing many people of color to be mass imprisoned for minor nonviolent drug offenses. Typically these charges involve trivial amounts of marijuana, which evinces the urgency for a more profound legalization debate; especially, because it is estimated that the "...legalization and sale of currentlyillicit drugs would yield $\$ 46.7$ billion in annual tax revenue," the same as alcohol and tobacco (Frontline, 2012). Naturally, legalizing drugs would lower incarceration rates, which is particularly relevant for nonviolent marijuana users that in 2010 comprised the 853,838 arrestees for petty marijuana law violations, and the 750,591 (88\%) arrested only for marijuana possession (Frontline, 2012). In New York City specifically, "What we're seeing is...a worst-case scenario," where there were "500,000 marijuana arrests in the last 10 years," and "NYPD spends $\$ 75$ million a year" on "stop and frisk" illegal arrests (Gray, 2011).

The "decriminalization of marijuana," has been a longstanding thorn in the side of countless "recreational users" in New York City-which has the highest per capita arrest rate for marijuana of any locale nationwide-and because New York State decriminalized "personal possession of marijuana weighing no more than $7 / 8$ of an ounce in 1977," which would render a possible a $\$ 100$ fine (Gray, 2011), but if an individual puts the marijuana on "public view, it becomes a misdemeanor," rendering an arrest, a fine, and up to three-months in prison (Drug Policy Alliance, 2012b). The Alliance reported since the mid-1990s, "officers have abused a legal loophole by tricking" mostly young people of color into "publicly revealing any concealed marijuana" in pockets or handbags by demanding "empty their pockets" or "open your bag," and then make the subsequent "public view" arrest for what should legally be a noncriminal civil citation (Drug Policy Alliance, 2012b). As a result, in 2010 there were 54,000 marijuana arrests in New York State, 50,000 were in predominantly "black, Latino and low income" NYC neighborhoods, making the "illegal arrests" a "clear case of racial injustice" (Gray, 2011).
To establish a clearer picture, Newman, Rhee and Carrasquillo (2011) reported that only 34,000 people were arrested for marijuana possession between 1981 and 1995, in contrast over the last 15 years over 600,000 individuals were arrested for marijuana possession, and of the 50,000 arrested for marijuana possession in 2011 , nearly $85 \%$ were black and Latino, despite federal governmental data that shows whites smoke marijuana at higher rates (Gray, 2011). These figures exhibit the racialization of arrestees that fall prey to NYPD's deceitful tactics. In September 2011, New York Police Commissioner Ray Kelly ordered all NYPD officers to stop charging people with misdemeanor marijuana violations "based on improper searches," which will lead to the yearly reduction of tens of thousands of marijuana arrests. The new policy directive came "on the heels" of a 2011 report "Up in Smoke," highlighting the enormous costs of marijuana arrests in New York and a public pressure campaign led by the Drug Policy Alliance, and an assortment of legalization advocates whose statistics "say it all."

Ironically, the "stop and frisk" policy and subsequent arrests have fueled the Prison Industrial Complex in New York State where the private prison industry was founded, "upstate" (Schlosser, 1998).

\section{Local and Regional Policies That Fuel the Broader Immigration Industrial Complex}

To fuel the Immigration Industrial Complex, a succession of antiimmigrant policies have reflected the antiimmigrant sentiment steeped in the public psyche amongst xenophobic politicians, hate groups, and law enforcement, which permits a concerted justification for making unauthorized immigrants vulnerable for mass incarceration. Operation Streamline is one example of these policies that was implemented in 2005 by former President George W Bush, garnering enormous profits for private prison profiteers in Southern Arizona (Gambino, 2010). Moreover, the complex program charges first-time bordercrossers up to a maximum of six months but oftentimes most offenders are "sentenced to time served and deported." Whereas, repeat offenders can receive up to two years in prison but typically draw a 10 to 180 day stint, however if a repeat offender has a criminal record, he or she can receive a up to a 20 years prison sentence (Gambino, 2010)

A call by Arizona's senators Kyl and McCain to fully implement Streamline would mean prosecuting all bordercrossers apprehended daily in the Tucson 
Sector instead of the $10 \%$ currently entering the program, and would drive costs in that sector alone to over $\$ 1$ billion in detentions (Gambino, 2010). In 2009, modest estimates for operating Streamline in Arizona fell between $\$ 10$ million and $\$ 11$ million per month, included was $\$ 3.6$ million for defense attorneys representing immigrant defendants, and nearly $\$ 3$ million for approximately 87 contract attorneys charging $\$ 110$ an hour, conversely it cost $\$ 70.75$ per day to detain 16,584 individuals processed through Streamline in the Tucson court and 1,877 in the Yuma court for average 30 day sentences, totaling $\$ 40$ million dollars (Gambino, 2010). Gambino reported that "expansion would require a new federal courthouse, more detention and prison centers, additional magistrates, district judges, federal marshals, Border Patrol agents, attorneys, interpreters and courtroom clerks" (3). The Arizona Senator's attempted to attach a $\$ 200$ million amendment to a policy under debate, but it was voted down.

These numbers mirror those in Texas where since the inception of Operation Streamline resulted in a $136 \%$ increase in prosecutions for unauthorized entry and an $85 \%$ increase in prosecutions for unauthorized reentry, totaling 135,000 prosecuted under the two statutes that make entry and reentry a crime in the Western and Southern Districts (Buentello, Carswell, Hudson \& Libal, 2010). According to the researchers, Operation Streamline has funneled more than $\$ 1.2$ billion into the largely for-profit private detention system in Texas, driving the expansion of private prisons along the border. These types of localized federal policies coupled with the traditional apprehension during street checkpoints, "roving," port of entry, and workplace and home raids, escalated the demand for more prison beds and saved the private prison industry that had "overbuilt speculative prisons," by paying its two top companies a total of $\$ 2.8$ billion since 9.11 (Barry, 2009). Despite the decline in the number of bordercrossers and crime along the border and beyond, the mass imprisonment of immigrants continues to explode, which has lucratively fueled and sustained the Immigration Industrial Complex that has served to eradicate hundreds of thousands of immigrants from society.

\section{DISCUSSION}

This paper considered the parallels between the black and Latino immigrant experiences relative to the Prison and Immigration Industrial Complexes, and found that in practicum both of these private prison industries have been utilized as "weaponry" in the "low intensity conflict war" on empowered blacks in the "post-Civil Rights Movement era," and on the "demographic threat" Latinos pose in the coming era of the "Browning of America." The Prison and Immigration Industrial Complexes have been successfully "disappearing" these groups of color from society and into mass imprisonment, thus keeping them "in their place." The ethnodistillation theoretical approach that I developed in this paper is motivated by the existence of the private prison industry, but also takes into account the "stereotyping" that blacks and Latino immigrants experience, the federal policies that have sustained it, and the local and regional policies that "fuel" it, but at the end of the day the theoretical process underscores that the culmination of these components put into action, is the aspiration-whether intentional or not-to preserve the dissipating white hegemonic order.

Despite the "uncompromising" DC climate, there was a glimmer of "bipartisan" hope for predominately blacks who are charged with more crack-related crimes, when President Obama signed The Fair Sentencing Act on August $3^{\text {rd }}, 2010$, declaring "It's the right thing to do" because it would "...right a longstanding wrong by narrowing sentencing disparities between...crack cocaine and powder cocaine" (Jackson, 2010). The 2010 Act was projected to reduce the prison population by thousands, and save taxpayers $\$ 42$ million in a half decade. While this was triumphant for black and civil rights communities, Latino immigrants are still hampered in the media by deliberate and or "dog whistle" messages via irresponsible journalists and politicians that have over the years polished their racially-coded discourse on "get tough-on-crime" policies. Arizona Governor Jan Brewer stooped to fearmongering during a television interview, stating "...almost all illegal immigrants are bringing drugs across the border" and "beheaded bodies" were being found in the desert. After a cursory investigation, the media, county coroner, nor ICE, could confirm Brewer's deceitful claims, but reported violent crimes and bordercrossings were cut in half since 2004.

The media's investigation also uncovered a remarkable link between Governor Brewer and the Immigration Industrial Complex. Paul Senseman, Brewer's deputy chief of staff, is a former lobbyist for Corrections Corporation of America, and his wife is a current lobbyist for the company; and, Chuck Coughlin is one of Brewer's policy advisers and campaign 
chairman, is owner of High Ground Public Affairs Consultants, and currently lobbies for CCA. Currently, CCA is federally contracted to house detainees in Arizona for $\$ 11$ million per month. The CBS 5 investigation posited that CCA would gain the most from the implementation of statewide and regionalized antiimmigration measures such as SB 1070 and Operation Streamline that fuel the private prison industry. While this is a sheer glimpse into the connection between policymakers and the Immigration Industrial Complex, and because of the scarcity yet growing research in this area, this evidence challenges other students and scholars of this immense industry to undertake de rigueur investigations capturing its campaign contribution, lobbying, and "kickback" power ${ }^{5}$.

The Asian and Pacific Islander American Scholarship Fund (APISASF) recipient bloggers (2012) asserted that the "model minority" paradigm has plagued the Panethnic Asian community since its introduction in 1960 by sociologist William Peterson, who compared Japanese Americans to blacks and credited "family values and strong work ethic" in Japanese culture for preempting Japanese Americans from becoming a "problem minority" such as "other minorities." Moreover, the "model minority" paradigm has created much inter and intraethnic controversy by pitting racial and Panethnic Asian groups against each other and has produced overgeneralizations that craft negative implications for all groups of color (APIASF, 2012). The controversial paradigm has consistently downplayed the structural discrimination that communities of color have experienced (Chin, 2012), and used to highlight the upward mobility of Asian Americans despite their being a nonmonolithic group evinced by the educational and socioeconomic statuses of Hmong, Philippine, Laotian and Cambodian Asian Americans, which differ greatly from their Eastern and Southern Asian counterparts. According to Sandhu (2012) social and psychological forces to conform to the model minority stereotype has placed

\footnotetext{
${ }^{5}$ In one case of corruption involving Pennsylvania Judge Mark Ciavarella Jr., a 28 year sentence for racketeering was levied upon him for accepting $\$ 1$ million in bribes from the developers of juvenile detention centers in exchange for his levying lengthier than normal sentences for thousands of victims (Tunde, 2012). The Pennsylvania Supreme Court dismissed roughly 4,000 convictions issued by Judge "Kids for Cash" Ciavarella between 2003 and 2008 on the grounds that he violated the constitutional rights of the juveniles (Associated Press, 2011).

${ }^{6}$ Peterson, William. (1960). "Success Story: Japanese American Style." New York Times Magazine.
}

an inordinate amount of pressure on Asian Americans, resulting in debilitating consequences ${ }^{7}$.

Although overcoming the "model minority" stereotype has been a struggle for the Panethnic Asian community decades, the challenge to researchers in the coming years will be documenting the demographic, socioeconomic, political, and educational impact that Asian immigrants will have on the changing fabric of the US, and the future reposition that the dominant class will launch on them in light of the historical restrictive policies that targeted Asian immigrants in the late $19^{\text {th }}$ through early $20^{\text {th }}$ centuries. Americans typically assume that bias is "...always targeted downward at the weakest and most vulnerable" in society, and oftentimes relate the "American Dream" to the Asian experience, but both assumptions are arguable (Rodríguez, 2012). Rodríguez paralleled Asians to the Jewish community, who for their "success" have been discriminated in the US for years ${ }^{8}$; therefore, Asians could also become vulnerable in this "...dawn of a new era of anti-Asian bias."

According to Rodríguez (2012), Asian Americans have the highest-income, are the best-educated and fastest-growing racial group in the US, and in recent years Asian immigrants have overtaken the number of new Latinos immigrants to the US. The author reported that the median household income of Asian Americans is now " $33 \%$ higher than that of the general public," 6 in 10 Asian immigrants come to the US with a bachelors degree, Asians gaining admittance to the California public university system are in some cases making up nearly half of the student body ${ }^{9}$, all of which coincide with the "rise of Asian Americans," China's emergence as a global power and as competition with China heats up, Asian Americans may feel the brunt of any antiChina sentiment (Rodríguez, 2012). History has shown that bigots hardly care about their targeted groups'

${ }^{7}$ Sandhu, Daya. (2012). "Several mental health concerns and psychological afflictions, such as threats to cultural identity, powerlessness, feelings of marginality, loneliness, hostility and perceived alienation and discrimination remain unredressed and hidden under the veneer of the model minority myth. Both social and psychological forces to conform to the model minority stereotype place an inordinate amount of pressure on Asian Americans." (see references-Chin, 2012).

${ }^{8} \mathrm{~A}$ decade or so ago, a prominent conservative political writer went so far as to tell me off the record of his suspicion that a large portion of Jewish philanthropy is motivated by a desire to defuse envy over the income disparity between the Jewish and Gentile populations (see Rodríguez, 2012).

"UC Irvine (AKA "University of Chinese and Indians") has an undergraduate student body that is 49\% Asian, and UC Los Ángeles (AKA "University of Caucasians Lost Among Asians") had a 2011 freshman class that was 41\% Asian American (see Rodríguez, 2012). 
distinctions; simply "looking the part" can make you a target of racism (Díaz, 2011) ${ }^{10}$.

Americans should not be surprised if they begin hearing demands for "the end of highly skilled immigration from Asia," and understand that the "distrust or disdain of Jews can sometimes be motivated by envy and resentment of an identifiably separate group that's significantly wealthier than the population at large," all of which suggest that "...invidious comparisons between groups are alive...[and can be] stoked by economics that, though not particularly venomous in the US right now, [may] have the potential to become dangerous under the wrong circumstances" (Rodríguez, 2012: 2). While the scope of this study focused on the Latino and black incarcerations, extensive study is necessary to investigate any increase in Asian incarcerations in coming years to document whether the ethnodistillation theoretical framework can be applied to the Asian experience in the coming "Browning of America," or whether their socioeconomic status can secure their exculpation from mass imprisonment. More than anything else, Rodríguez (2012) stated that "race relations American-style have always been about sharp elbows and hunger for a piece of the pie." Therefore, students of the Asian experience in the US should heed just how "hungry" the dominant class is in maintaining control of the "pie," and with whom it is willing to share, or not.

This study conjoined the black experience and Prison Industrial Complex literature, with the immigration and crime and Immigration Industrial Complex literature to develop the ethnodistillation theoretical paradigm to explain the "disappearance" of people of color from US society by way of mass imprisonment. Indeed, the so-called "War on Drugs" has undoubtedly fed the private detention industry by hypercriminalizing people of color. It is no doubt the low intensity "urban war" on blacks has run concomitant to the rise of the Prison Industrial Complex, and now the low intensity "border war" on Latino immigrants and the rise of the Immigration Industrial Complex. This theoretical approach also considered the stereotypical vilification and demonization of people of color, and the implementation of local and regional policies that make

\footnotetext{
${ }^{10}$ Last week saw the 30th anniversary of the killing of Vincent Chin, a Chinese American in Michigan who died after he was beaten by two out-of-work autoworkers who blamed him for competition from the Japanese automobile industry (see Rodríguez, 2012).
}

them first vulnerable to the criminal justice system and then possible "disappearance" into the PIC and or IIC.

In sum, Latino immigrants represent a future electoral threat against the white hegemonic order, which became exceptionally evident in the overwhelming support of Latino voters' role in the 2012 reelection of the first US president of color. Therefore, in their postelection analysis antiimmigrant forces in the highest rungs of politics have suggested to not only deny immigrants the opportunity to adjust their citizenship and or vote for a minimum of 20 years, but have doubled down calling once again for mass "self deportation." Nevertheless, there is ample evidence that they are still being detained and eradicated from society vis-à-vis the IIC, much like in the post-civil rights era, when young black males were eradicated from society by the urban "War on Drugs" and the rise of the PIC. As such, this study has shown that the implications for policymaking has hinged on the motivation of federal policymakers and presidential administrations in the post-civil rights era to "disappear" empowered blacks beginning with the Nixon Administration's reaction to the "incited lawlessness" prompted by civil disobedience and peaceful demonstrations, then policies shifted under the Reagan, Clinton, Bush Jr., and Obama Administrations to also "disappear" Latino immigrants who pose the next political, economic, and demographic threat by 2050 in the looming Browning of America.

\section{ACKNOWLEDGEMENT}

Special Thanks to Jake Wilson and Marigrace Díaz for their feedback on earlier drafts and editing contributions to this paper, and the Reviewers for their time and effort in the process.

\section{REFERENCES}

Aguirre, Adalberto Jr. \& Turner, Jonathan. (1995). American Ethnicity: The Dynamics and Consequences of Discrimination. New York, NY. McGraw-Hill, Inc.

Akers Chacón, Justin \& Davis, Mike. (2006). "The Anti-Filipino Riots." No One Is Illegal: Fighting Racism and State Violence on the US-México Border, chapter 5. Chicago, Illinois. Haymarket Books. 39-42.

Allen, JoAnne. (1999). Blaxploitation Films. http://besser.tsoa.nyu.edu/impact/s99/Projects/paper/joanne. html. Retrieved June $29^{\text {th }}, 2012$.

Alexander, Michelle. (2012). The New Jim Crow: Mass Incarceration in the Age of Colorblindness. New York, NY. The New Press.

Alimahomed, Sabrina. (2011). Generation Islam": Arab American Muslims and Racial Politics after September 11. Race/Ethnicity: Multidisciplinary Global Contexts, 4, 3. 381397. 
Almaguer, Tomás. (1994). Racial Faultines: The Historical Origins of White Supremacy in California. London, England. University of California Press.

Asian \& Pacific Islander American Scholarship Fund Recipient Blog. (2012). May 25/ Visibly Invisible. Posted May 5 $5^{\text {th }}, 2012$. http://apiasfrepresent.tumblr.com/post/23734836190. Retrieved November $23^{\text {rd }}, 2012$.

Barry, T. (2009). A Death in Texas: Profits, poverty, and immigration converge. Boston Review. Retrieved from: http://bostonreview.net/BR34.6/barry.php. Retrieved January $29^{\text {th }}, 2011$.

Boudreaux, Don. (2006). Are Immigrants to Blame for Inappropriate Government Activities? Cafehayek.com. May 19 2006. http://cafehayek.com/2006/05/are immigrants .html. Retrieved June $24^{\text {th }}, 2012$.

Bowler, Alida. (1931). Wickersham Commission: National Commission on Law Observance and Enforcement: Crime and the Foreign Born. U.S. Government Printing Office. Washington DC.

Brotherton, David \& Kretsedemas, Philip. (2008). Keeping Out The Other: A critical introduction to immigration enforcement today. New York, NY. Columbia University Press.

Buentello, T., Carswell, S., Hudson, N. \& Libal, B. (2010). Operation Streamline: Drowning Justice and Draining Dollars along the Rio Grande. Grassrootsleadership.org. July 2010. www.grassrootsleadership.org

http://grassrootsleadership.org/OperationStreamline/wpcontent/uploads/2010/08/Operation-Streamline-GreenPaper.pdf. Retrieved June $12^{\text {th }}, 2012$.

Butcher, K., Piehl, \& Morrison, A. (1999). The role of deportation in the incarceration of immigrants. National Bureau of Economic Research. Working Paper.

Butcher, K., Piehl \& Morrison, A. (1998a). Recent Immigrants: Unexpected implications for crime and incarceration. Industrial and Labor Relations Review, 51. 654-679. http://dx.doi.org/10.2307/2525013

Butcher, K., Piehl \& Morrison, A. (1998b). Cross-city evidence on the relationship between immigration and crime. Journal of Policy Analysis and Management, 17. 457-493.

http://dx.doi.org/10.1002/(SICl)1520-

6688(199822)17:3<457::AID-PAM4>3.0.CO;2-F

Ceasar, Stephen. (2011). Hispanic population tops 50 million in US. Los Angeles Times. March 24, 2011. http://articles.latimes.com/print/2011/mar/24/nation/la-nacensus-hispanic-20110325. Retrieved June 20 2012.

Chin, Andrew. (2001). A Brief History of the "Model Minority" Stereotype. Model Minority. April 21, 2001. http://modelminority.com/joomla/index.php?option=com_cont ent\&view=article\&id=113:a-brief-history-of-the-modelminority-stereotype-\&catid=40:history \& Itemid $=56$. Retrieved November $25^{\text {th }}, 2012$.

Clark, Kenneth, B. \& Clark, Mamie, K. (1940). Skin color as a factor in racial identification of Negro preschool children. Journal of Social Psychology, S.P.S.S.I. Bulletin, 11. 159-169. http://dx.doi.org/10.1080/00224545.1940.9918741

Department of Homeland Security. (2009). Immigration Detention Overview and recommendations. Department of Homealand Security. October $6^{\text {th }}$, 2009. http://www.ice.gov/doclib/ 091005_ice_detention_report-final.pdf Retrieved June $12^{\text {th }}$, 2012.

DeSipio, Louis. (1996). Counting on the Latino Vote: Latinos as a New Electorate. Charlottesville, VA. University Press of Virginia.

Detention Watch Network. (2009). Advocate issue statement condemning Obama Administration. Press Release. July $17^{\text {th }}, 2009.1-3$.

Díaz, Jr., Jesse. (2010). Organizing the brown tide: La Gran Epoca Primavera 2006 en Los Angeles, an Insider's Story. University of California, Riverside. Dissertation in Sociology.
Díaz, Jr., Jesse. (2011). Immigration Policy, Criminalization and the Growth of the Immigration Industrial Complex: Restriction, Expulsion, and Eradication of Undocumented in the U.S. Western Criminology Review 12, 2. 35-54.

Douglas, K. \& Saenz, R. (2009). "The making of a criminal: Immigrants and the prison industrial complex." Presentation at the University of Nebraska, Omaha www.unomaha.edu/ollas/.../saenz\%20power\%20point.ppt.

Drug Policy Alliance. (2012a). History of the Drug War. Drug Policy Alliance. http://www.drugpolicy.org/facts/new- solutions-drugpolicy/brief-history-drug-war. Retrieved January 20 ${ }^{\text {th }}, 2012$.

Drug Policy Alliance. (2012b). Our Victories: Most Recent Victories. Drug Policy Alliance. http://www.drugpolicy.org/action/ourvictories. Retrieved January $24^{\text {th }}, 2012$.

Dunn, Timothy. (1996). The Militarization of the U.S.-Mexico Border 1978-1992: Low-Intensity Conflict Doctrine Comes Home. Austin, TX. CMAS Books.

Eitzen, Stanley D. \& Baca Zinn, Maxine. (2007). In Conflict and Order: Understanding Society. Boston, MA. Pearson, Education, Inc.

Farlex. (2008). Slavery. Farlex: The Free Dictionary. http://legaldictionary.thefreedictionary.com/slavery. Retrieved May $29^{\text {th }}$, 2012.

Feagin, Joe. (2000). Racist America: Roots, Current Realities, and Future Reparations. New York, NY. Routledge.

Fernándes, Deepa. (2007). Targeted: Homeland Security and the Business of Immigration. New York, NY. Seven Stories Press.

Frontline. (2012). Thirty Years of America's Drug War: A Chronology. Frontline. http://www.pbs.org/wgbh/pages/frontline/shows/dru gs/cron/. Retrieved June $12^{\text {th }}, 2012$.

Gambino, Lauren. (2010). Operation Streamline Program Prosecutes Illegal Immigrants Before Deporting Them. News 21: Latino America. http://asu.news21.com/2010/prosecuting-illegalimmigrants/. Retrieved July $15^{\text {th }}, 2012$.

Gavett, Gretchen. (2011). Lost in Detention Map: The U.S. Immigration Detention Boom. Frontline. October $18^{\text {th }}, 2011$. http://www.pbs.org/wgbh/pages/frontline/lost-in-detention/. Retrieved June $20^{\text {th }}, 2011$.

Golash-Boza, Tanya. (2009a). A confluence of interests in immigration enforcement: How politicians, the media, and corporations profit from immigration policies destined to fail. Sociology Compass, 3. 1-12.

Golash-Boza, Tanya. (2009b). The Immigration Industrial Complex: Why We Enforce Immigration Policies Destined to Fail Sociology Compass, 3. 1-15.

Gray, Katti. (2011). News Report, How Cops Turn "Stop and Frisk" Into "Stop and Arrest." The Root. June 13 $13^{\text {th }}, 2011$. http://newamericamedia.org/2011/06/how-cops-turn-stopand-frisk-into-stop-and-arrest.php. Retrieved June 15 $5^{\text {th }}, 2012$.

Gray, Madison. (2009). New York's Rockefeller Drug Laws. Time. April $2^{\text {nd }}, 2009$. http://www.time.com/time/nation/article/ 0,8599,1888864,00.html. Retrieved June $12^{\text {th }}, 2012$

Hallinan, Joseph. (2001). Going Up the River: Travels in a Prison Nation. New York, NY. Random House Publishers

Harding, Vincent. (1981). There is a River: The Black Struggle for Freedom in American. New York, NY. Harcourt-Brace Jovanovich Publishers.

Herzing, Rachel. (2005). What is the prison industrial complex. Publiceye.org. http://www.publiceye.org/defendingjustice/ overview/herzing_pic.html. Retrieved May $8^{\text {th }}, 2012$

Horowitz, Carl. (2001). An examination of US immigration policy and serious crime. Center for Immigration Studies.

Horton, Y., Price, R. \& Brown, Eric. (1999). Portrayal of Minorities in the Film, Media and Entertainment Industries. Poverty \& Prejudice: Media and Race: Edge ethics of development in a global environment. June $1^{\text {st }}$, 1999. http://www.stanford.edu/ 
class/e297c/poverty_prejudice/mediarace/portrayal.htm. Retrieved June14th, 2012.

Hourwich, I. (1912). Immigration and Crime. The American Journal of Sociology 17,4 . 478-490.

Hsu Spencer \& Moreno, Sylvia. (2007). US: Border Policy's Success Strains Resources: Tent City in Texas Among Immigrant Holding Sites Drawing Criticism. The Washington Post. Corpwatch: Holding Corporations Accountable. February $2^{\text {nd }}$, $2007 . \quad \mathrm{http}: / / \mathrm{www}$.corpwatch.org/article.php?id=14334\& printsafe $=1$. Retrieved July $2^{\text {nd }}, 2012$.

Immigration Customs and Enforcement. (2012). Secure Communities. Department of Homeland Security. http://www.ice.gov/secure_communities/. Retrieved June 14th, 2012.

Jackson, David. (2010). Obama signs law targeting disparities in cocaine cases. USA Today. Aug 3rd, 2010. http://content.usatoday.com/communities/theoval/post/2010/ 08/obama-signs-law-targeting-disparities-in-cocaine-cases/1. Retrieved July $23^{\text {rd }}, 2012$.

Jackson Lee, Sheila. (2001). Review of Department of Justice Immigration Detention Policies. Subcommittee on the Judiciary House of Representatives, $107^{\text {th }}$ Congress, $1^{\text {st }}$ Session. December $19^{\text {th }}$.

Kang, Cecilia. (2007). Customs Enlists Rosetta to Train Officers' Tongues. Washington Post. Monday, October $22^{\text {nd }}, 2007$. http://dreamacttexas.blogspot.com/2007/10/more-money-inimmigration-industrial.html. Retrieved June $13^{\text {th }}, 2012$.

Kelsey, C. (1926). Immigration and Crime. Annals of the American Academy of Political and Social Science, 125. 165-174. http://dx.doi.org/10.1177/000271622612500132

Kennedy, Bud. (2006). Few minutes with Minuteklan is plenty of time for GOP group. Star-Telegram. June $29^{\text {th }}, 2006$. http://minuteklannews.blogspot.com/2006/06/few-minuteswith-minuteklan-is-plenty.html. Retrieved May 25 $5^{\text {th }}, 2011$.

Kil, Sang Hea \& Menijvar, C. (2006). The War on the Border: Criminalizing immigrants and militarizing in US-México Border. In Immigration and Crime: Race, Ethnicity and Violence. Edited by Ramiro Martinez, Jr. and Abel Valenzuela, Jr. New York, NY. New York University Press.

Lee, Matthew. (2003). Crime on the Border: Immigration and Homicide in Urban Communities. New York, New York. LFB Scholarly Publishing.

Lydersen, Kari. (2007). Families Behind Bars: Jailing Children of Immigrants. In These Times. <www.alternet.org/story/ 48308.>. Retrieved July $16^{\text {th }}, 2012$.

Martin, Courtney. (2009). The Big Business of Family Detention: It's not just alleged terrorists who are suffering from our inhumane treatment of detainees. It's also children. The American Prospect. February $2^{\text {nd }}, 2009$. http://prospect.org/article/big-business-family-detention. Retrieved June $13^{\text {th }}, 2012$.

Martínez, Ramiro, Jr. (2000). Immigration and urban violence: The link between immigrant Latinos and types of homicide. Social Science Quarterly, 81. 363-374.

Martínez, Ramiro Jr. \& Valenzuela, Abel. (2006). Immigration and Crime: Race, ethnicity, and violence. New York, NY. New York University Press.

Martínez, Ramiro, Stowell, Jacob \& Lee, Matthew. (2010). Immigration and crime in an era of transformation: A longitudinal analysis of homicides in San Diego neighborhoods, 190-2000. Criminology, 48, 3. 797-829. http://dx.doi.org/10.1111/j.1745-9125.2010.00202.x

Massey, D. (1995). The New Immigration and Ethnicity in the United States. Population and Development Review, 21, 3. 631-652. http://dx.doi.org/10.2307/2137753

Massey, D., Durand, J. \& Malone, J. (2002). Beyond Smoke and Mirrors. New York, NY. Russell Sage Foundation.
Mauer, Marc. (2009). The Changing Racial Dynamics of the War on Drugs. The Sentencing Project: Research and Advocacy for Reform. April 2009. http://www.sentencingproject.org/doc/ dp_raceanddrugs.pdf. Retrieved June $12^{\text {th }}, 2012$.

McAdam, Doug. (1999, 1982). Political Process and the Development of Black Insurgency, 1930-1970. Chicago, IL. University of Chicago Press.

McCann, Brian. (2007). Fighting the Prison Industrial Complex: A Call to Communication and Cultural Studies Scholars to Change the World. Communication and Critical/Cultural Studies, 4,4. 402-420.

McLaughlin, Virginia Yans. (1990). Immigration Reconsidered: History, Sociology, and Politics. New York, NY. Oxford University Press.

Morawetz, Nancy. (2000). Understanding the impact of the 1996 deportation laws and the limited scope of proposed reform. Harvard Law Review, 113, 8. 1936-1962. http://dx.doi.org/10.2307/1342314

Newman, T., Rhee, K. \& Carrasquillo, A. (2011). NY Governor Cuomo Announces Support for Closing Major Loophole in State's Marijuana Decriminalization Law; Bloomberg and Kelly Follow Suit. Drug Policy Alliance. June $4^{\text {th }}, 2012$ http://www.drugpolicy.org/news/2012/06/ny-governor-cuomoannounces-support-closing-major-loophole-states-marijuanadecriminali. Retrieved June $20^{\text {th }}, 2012$.

New York Times. (2009). Editorial: Enforcement gone bad. New York Times. February $22^{\text {nd }}, 2009$.

Ngai, Mae. (2004). Impossible Subjects: Illegal Aliens and the Making of Modern America. Princeton, NJ. Princeton University Press.

Oboler, Suzanne. (2009). Behind Bars: Latino/as and Prison in the United States. New York. NY. Palgrave Macmillan.

One People's Project. (2005). Minuteman Co-Founder Joins Hate Group. Onepeoplesproject.com. July, $2^{\text {nd }}, 2005$. http://www.onepeoplesproject.com/. Retrieved July $12^{\text {th }}$, 2012.

Ong Hing, B. (2004). Defining American through Immigration Policy Philadelphia, PA. Temple University Press.

Pettit, B. \& Western, B. (2004). Mass Imprisonment and the Life Course: Race and Class Inequality in US Incarceration. American Sociological Review, 69, 2. 151-169. Retrieved from www.jstor.org.torofind.csudh.edu/stable/3593082. Retrieved May $8^{\text {th }}, 2012$.

Powell-Hopson, Darlene \& Hopson, Derek S. (1988). Implications of Doll Color Preferences among Black Preschool Children and White Preschool Children. Journal of Black Psychology, 14. 57-63. http://dx.doi.org/10.1177/00957984880142004

Rodriguez, Gregory. (2012). New wave of immigrants - a new target too? Asian Americans are the highest-income, best-educated and fastest-growing racial group in the U.S. This means envy and resentment may follow, Op-Ed. latimes.com. June 25, 2012. latimes.com/news/opinion/commentary/la-oe-0625rodriguez-pew-asians--20120625,0,6955824.column. Retrieved November 28 ${ }^{\text {th }}, 2012$.

Roth, Mitchel. (2011). Crime and Punishment: A history of criminal justice system. Belmont, CA. Wadsworth, Cengage Learning.

RT America. (2012). DHS wants to use spy drones domestically for "public safety." RT America. July 26 ${ }^{\text {th }}, 2012$. http://rt.com/usa/news/dhs-drone-surveillance-napolitano156/. Retrieved June 24 ${ }^{\text {th }}, 2012$.

Samora, Julian. (1971). Los Mojados: The Wetback Story. Notre Dame, IN. University of Notre Dame Press.

Sampson, R. (2006). Open doors don't invite criminals. New York Times. March $11^{\text {th }}$

Savive, Will. (2012). Dimensions of Racial Profiling \& Institutionalized Racism in the US Savive's Corner. Thursday, January $12^{\text {th }}$, 
2012. http://willsavive.blogspot.com/2012_01_01_archive. html. Retrieved June 12 $2^{\text {th }}, 2012$.

Schlosser, Eric. (1998). The Prison-Industrial Complex. Atlantic Monthly. December 1998. http://www.theatlantic.com/ magazine/archive/1998/12/the-prison-industrialcomplex/4669/. Retrieved April 15 ${ }^{\text {th }}, 2011$.

Siegal, Larry \& Bartollas, Clemens. (2011). Corrections Today. Belmont, CA. Wadsworth, Cengage Learning.

Siegal, Larry \& Welsh, Brandon. (2012). Juvenile Delinquency: Theory, Practice, and Law. Belmont, CA. Wadsworth: Cengage Learning.

Southern California Immigration Coalition. (2009). The Southern California Immigration Coalition supports workers' demands that the Obama administration stop the rampant 19 audits and $E$ Verify resulting in the terminations of tens of thousands of workers. Press Release. July $18^{\text {th }}, 2009$.

Suro, Roberto. (1996). Watching America's Door: The Immigration Backlash and the New Policy Debate. New York, NY. The Twentieth Century Fund Press.

Thompson, Gabriel. (2011). How the Right Made Racism Sound Fair-and Changed Immigration Politics. Colorlines: News for
Action. September $13^{\text {th }}, 2011$. http://colorlines.com/archives/ 2011/09/how_the_right_made_racist_rhetoric_sound_neutral --and_shaped_immigration_politics.html. Retrieved July $2^{\text {nd }}$, 2012.

Vogel, Richard. (2007). Transient Servitude: The U.S. Guest Worker Program for Exploiting Mexican and Central American Workers. Monthly Review, 58, 8. Posted Jan. 2007. http://monthlyreview.org/2007/01/01/transient-servitude-theu-s-guest-worker-program-for-exploiting-mexican-andcentral-american-workers. Retrieved June $3^{\text {rd }}, 2012$.

Wessler, Seth. (2011). Shattered families: The perilous intersection of immigration enforcement and the child welfare system. Applied Research Center. November 2011. http://arc.org/shatteredfamilies. Retrieved June 14 ${ }^{\text {th }}, 2012$.

Wilder, Forrest (2006). South Texas Hold 'Em: The Immigration Endgame. Texas Observer. Thursday, May $4^{\text {th }}, 2006$. http://www.texasobserver.org/archives/item/14795-2193south-texas-hold-em-the-immigration-endgame. Retrieved April $10^{\text {th }}, 2011$.

DOI: http://dx.doi.org/10.6000/1929-4409.2012.01.24

(C) 2012 Jesse Díaz Jr.; Licensee Lifescience Global.

This is an open access article licensed under the terms of the Creative Commons Attribution Non-Commercial License (http://creativecommons.org/licenses/by-nc/3.0/) which permits unrestricted, non-commercial use, distribution and reproduction in any medium, provided the work is properly cited. 